\title{
Czynniki wpływające na podnoszenie poziomu kwalifikacji zawodowych pielęgniarek w ramach kształcenia podyplomowego
}

\section{Factors affecting the improvement of professional qualifications of nurses in the course of postgraduate education}

\author{
ALEKSANDRA JAGODZIŃSKA ${ }^{1}$, LEOKADIA REZMERSKA² \\ ${ }^{1}$ Wojewódzki Szpital Specjalistyczny im. błogosławionego księdza Jerzego Popiełuszki \\ we Włocławku \\ ${ }^{2}$ Instytut Nauk o Zdrowiu PWSZ we Włocławku
}

DOI: http://dx.doi.org/10.21784/lwP.2017.022

ISSN: 2451-1846

\section{Streszczenie:}

Wstęp. Intensywny rozwój kształcenia podyplomowego pielęgniarek nastąpił po wstąpieniu Polski do Unii Europejskiej. Powstała wówczas potrzeba dostosowania poziomu wykonywania praktyki zawodowej w dziedzinie pielęgniarstwa do standardów europejskich. Obecnie system kształcenia pielęgniarek w Polsce odbywa się na zasadzie systemu bolońskiego $\mathrm{z}$ możliwością wykorzystania szerokiej oferty $\mathrm{w}$ ramach dokształcania i doskonalenia zawodowego. Kształcenie podyplomowe daje dużą możliwość systematycznego podnoszenia kwalifikacji i kompetencji zawodowych pielęgniarek.

Cel. Celem badań była analiza czynników wpływających na podnoszenie poziomu kwalifikacji zawodowych pielęgniarek $\mathrm{w}$ toku kształcenia podyplomowego. 
Materiał i metody. Badania wykonano wśród 71 osób będących studentami na kierunku pielęgniarstwo w Kujawskiej Szkole Wyższej we Włocławku. Badania przeprowadzono w styczniu 2017 roku. Badanymi osobami w zdecydowanej większości były kobiety, a dominujący wiek osób badanych to 36-50 lat. Dla wykonania badań zastosowano metodę sondażu diagnostycznego z użyciem kwestionariusza ankiety własnej konstrukcji.

Wyniki. Wyniki badań zostały poddane opracowaniu i analizie statystycznej oraz przedstawione graficznie w tabelach i na wykresach wraz z ich opisem.

Wnioski. 1. Czynnikami wpływającymi na podnoszenie poziomu kwalifikacji zawodowych pielęgniarek $\mathrm{w}$ toku kształcenia podyplomowego są: chęć uzyskania wyższego wynagrodzenia, korzystniejsze warunki zatrudnienia, podjęcie pracy zawodowej za granicą. 2. Czynniki wpływające na podnoszenie poziomu kwalifikacji zawodowych pielęgniarek $\mathrm{w}$ ramach kształcenia podyplomowego nie zależą od stażu pracy osób badanych, od wykształcenia zawodowego oraz zajmowanego stanowiska w pracy osób badanych.

Słowa kluczowe: kwalifikacje zawodowe, pielęgniarka, kształcenie podyplomowe

\begin{abstract}
:
Introduction. Intensive development of postgraduate education of nurses took place after Poland's accession to the European Union. At that time, there was a need to adjust the level of professional practice in nursing to European standards. At present, the nurses' education system in Poland is based on the Bologna system with the possibility of using a wide range of professional training and development. Postgraduate education offers a great opportunity to systematically improve the qualifications and professional competences of nurses.
\end{abstract}

Aim. The aim of the research was to analyse factors affecting the improvement of professional qualifications of nurses in the course of postgraduate education.

Material and methods. The study comprised of 71 people, nursing students at the Kujawska Szkoła Wyższa in Włocławek. The study was carried out in January 2017. The majority of respondents were women, and the dominant age of the respondents was 36-50 years. In order to carry out the research, 
the method of a diagnostic survey was applied with the use of a self-created questionnaire.

Results. The research results were processed and analyzed statistically and presented graphically in tables and graphs along with their description.

Conclusions. 1. The factors affecting the improvement of professional qualifications of nurses in the course of postgraduate education are: willingness to obtain higher remuneration, more favorable employment conditions, continuing professional career abroad. 2. The factors affecting the improvement of professional qualifications of nurses in the course of postgraduate education depend on the seniority of the respondents, but they do not depend on professional education or the job position of the respondents.

Keywords: professional qualifications, nurse, postgraduate education

\section{Wstęp}

Dokonująca się na przestrzeni ostatnich lat zmiana ustrojowa dotyczyła wielu dziedzin społecznych, w tym również w ochronie zdrowia. Zakłady opieki zdrowotnej musiały zareagować na zmiany i rozwój otoczenia. Pojawiła się nieznana do tej pory konkurencja w służbie zdrowia. Ministerstwo Zdrowia poprzez Kasy Chorych, a później Narodowy Fundusz Zdrowia wprowadziło system płatności za procedury lecznicze u danego pacjenta, co za tym idzie ilość otrzymywanych funduszy uzależniona została od ilości hospitalizowanych pacjentów. Zakłady opieki zdrowotnej zaczęły konkurować o pacjenta. To pacjent teraz mógł wybrać jednostkę służby zdrowia, w której chciał rozpocząć proces leczenia. Drugim etapem rozwoju służby zdrowia był dostęp do zagranicznej technologii medycznej. Nowoczesny specjalistyczny sprzęt zaczął docierać do naszych szpitali i przychodni. Kolejnym etapem zmian w służbie zdrowia było podejście do pracownika. Zauważono, że nie tylko rozwój technologii medycznej ma wpływ na proces dojścia do zdrowia pacjenta, ale także, a może przede wszystkim jakość opieki wobec chorego w jednostce służby zdrowia. Główny filar procesu opieki nad pacjentem stanowi personel pielęgniarski. To ta grupa zawodowa ma 
największy kontakt z pacjentem wykonując procesy pielęgnacji i opieki oraz zlecenia lekarskie. Aby personel pielęgniarski mógł sprostać tym zadaniom musi ciągle podnosić wiedzę i umiejętności poprzez udział w różnego rodzaju kursach, szkoleniach, konferencjach naukowych oraz studiach medycznych. Pracodawcy bardzo często aby zachęcić pracowników do dokształcania i doskonalenia zawodowego wprowadzają systemy motywacyjne, które najczęściej dotyczą gratyfikacji finansowej, ale również prestiżu, awansu zawodowego i wielu innych korzyści.

W zakresie oferty kształcenia podyplomowego dla pielęgniarek istnieją studia podyplomowe oraz kursy kwalifikacyjne, specjalistyczne i specjalizacje zawodowe w pielęgniarstwie. Specjalizacja trwa dwa lata i obejmuje średnio około 1000 godzin zajęć dydaktycznych. Można ją uzyskać $\mathrm{z}$ wielu różnych dziedzin, które są określone przez Rozporządzenie Ministra Zdrowia z 2013 roku, które dotyczy wykazu dziedzin pielęgniarstwa oraz dziedzin mających zastosowanie w ochronie zdrowia, w których może być prowadzona specjalizacja i kursy kwalifikacyjne. Kursy kwalifikacyjne mają na celu uzyskanie przez pielęgniarkę wiedzy i umiejętności do udzielania określonych świadczeń zdrowotnych wchodzących $\mathrm{w}$ zakres danej dziedziny pielęgniarstwa lub dziedziny mającej zastosowanie $w$ ochronie zdrowia. Warunkiem uczestnictwa $\mathrm{w}$ kursie jest posiadanie prawa wykonywania zawodu $[1,2]$.

Celem badań własnych była analiza czynników wpływających na podnoszenie poziomu kwalifikacji zawodowych pielęgniarek w ramach kształcenia podyplomowego.

\section{Materiał i metody}

Badania wykonano wśród 71 osób będących studentami na kierunku pielęgniarstwo w Kujawskiej Szkole Wyższej we Włocławku. Badania przeprowadzono w styczniu 2017 roku. Badanymi osobami 
w zdecydowanej większości były kobiety, a dominujący wiek osób badanych to 36-50 lat. Dla przeprowadzenia badań zastosowano metodę sondażu diagnostycznego z użyciem kwestionariusza ankiety własnej konstrukcji. Na wykonanie badań uzyskano zgodę Komisji Bioetycznej przy Kujawsko-Pomorskiej Okręgowej Izbie Lekarskiej w Toruniu - OIL-67/KB/149/2016. Dla opracowania wyników badań utworzono bazę danych programu Excel. Wszystkie obliczenia wykonano za pomocą pakietu statystycznego SPSS Statistica 21.0. Wyniki badań poddano analizie statystycznej, opisowej i graficznej. Zależności statystyczne pomiędzy analizowanymi cechami zbadano używając testu chi kwadrat dla prób niezależnych. Przyjęto ryzyko błędu wnioskowania na poziomie 5\%. Wartość prawdopodobieństwa $\mathrm{p}<0,05$ uznano za statystycznie istotną.

\section{Wyniki}

Uzyskane wyniki z badań własnych dotyczące głównych motywów decydujących o podjęciu dokształcania i doskonalenia zawodowego wśród pielęgniarek przedstawia poniższa tabela 1 i rycina 1.

Tabela 1. Motywy podjęcia kształcenia podyplomowego wśród pielęgniarek.

\begin{tabular}{|l|c|c|}
\hline \multicolumn{1}{|c|}{ Motywy } & $\mathrm{n}$ & $\%$ \\
\hline Wyższe wynagrodzenie & 29 & 39,4 \\
\hline Korzystniejsze zatrudnienie & 20 & 28,2 \\
\hline Praca za granicą & 16 & 22,5 \\
\hline Wymagania pracodawcy & 4 & 6,6 \\
\hline Satysfakcja zawodowa & 2 & 3,3 \\
\hline \multicolumn{1}{|c|}{ Razem } & 71 & 100,0 \\
\hline
\end{tabular}

Źródło: wynik badań własnych 


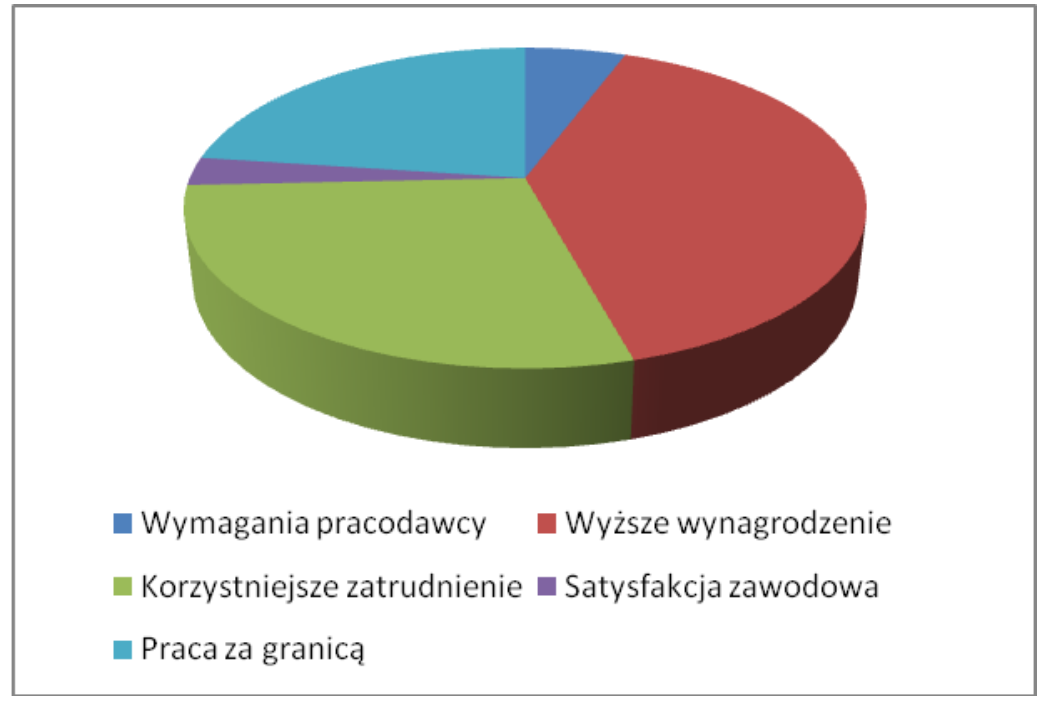

\section{Rycina 1. Rozkład motywów podjęcia kształcenia podyplomowego wśród pielęgniarek. \\ Źródło: wynik badań własnych}

Dokonując analizy powyższych danych uzyskanych z badań należy stwierdzić, że dla 39,4\% respondentów głównym czynnikiem wpływającym na decyzję o rozpoczęciu procesu dokształcania było perspektywiczne otrzymanie wyższego wynagrodzenia. Dla 28,2\% respondentów czynnikiem decydującym o podjęciu decyzji w zakresie rozpoczęcia dokształcania była możliwość zdobycia bardziej korzystnego zatrudnienia. W przypadku 22,5\% osób badanych na ich decyzję wpłynęła możliwość wyjazdu i podjęcia pracy zarobkowej za granicą. W bardzo niedużym zakresie, bo tylko dla 6,6\% respondentów na decyzję o podjęciu procesu dokształcania wpłynął nacisk i wymagania pracodawcy. W znacznie mniejszym zakresie, czyli 3,3\% badanych rozpoczęło proces dokształcania $\mathrm{w}$ związku $\mathrm{z}$ własną satysfakcją zawodową. Trzy główne, najczęściej wymieniane motywy podejmowania kształcenia podyplomowego, czyli perspektywa 
wyższego wynagrodzenia, możliwość korzystniejszego zatrudnienia oraz praca za granicą wiążą się ściśle ze sferą finansową.

Dalsza analiza uzyskanych wyników dotyczyła zbadania korelacji powyższych czynników decydujących o kształceniu podyplomowym pielęgniarek uczestniczących w badaniach w zależności od czynników zawodowych. Tabela 2 i rycina 2 prezentuje zestawienie czynników decydujących o podjęciu kształcenia podyplomowego w zależności od poziomu wykształcenia respondentów.

Tabela 2. Czynniki wpływające na podnoszenie poziomu wykształcenia podyplomowego pielęgniarek, a poziom wykształcenia zawodowego osób badanych.

\begin{tabular}{|c|c|c|c|c|c|c|c|c|c|c|c|}
\hline \multirow{2}{*}{$\begin{array}{l}\text { Czynniki } \\
\text { / poziom } \\
\text { wykształcen } \\
\text { ia }\end{array}$} & \multicolumn{2}{|c|}{$\begin{array}{c}\text { Wymaga } \\
\text { nia } \\
\text { pracoda } \\
\text { wcy }\end{array}$} & \multicolumn{2}{|c|}{$\begin{array}{c}\text { Wyższe } \\
\text { wynagrodz } \\
\text { enie }\end{array}$} & \multicolumn{2}{|c|}{$\begin{array}{c}\text { Korzystniej } \\
\text { sze } \\
\text { zatrudnien } \\
\text { ie }\end{array}$} & \multicolumn{2}{|c|}{$\begin{array}{c}\text { Satysfak } \\
\text { cja } \\
\text { zawodo } \\
\text { wa }\end{array}$} & \multicolumn{2}{|c|}{$\begin{array}{c}\text { Praca za } \\
\text { granicą }\end{array}$} & \multirow{2}{*}{ 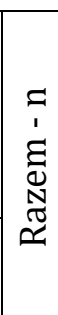 } \\
\hline & $\begin{array}{c}\mathrm{n}= \\
4\end{array}$ & $\%$ & $\begin{array}{l}\mathrm{n}= \\
28\end{array}$ & $\%$ & $\begin{array}{l}\mathrm{n}= \\
20\end{array}$ & $\%$ & $\begin{array}{c}\mathrm{n}= \\
2\end{array}$ & $\%$ & $\begin{array}{l}\mathrm{n}= \\
17\end{array}$ & $\%$ & \\
\hline $\begin{array}{l}\text { Średnie } \\
\text { medyczne }\end{array}$ & 0 & $\begin{array}{l}0, \\
0\end{array}$ & 2 & $\begin{array}{c}50 \\
0\end{array}$ & 1 & $\begin{array}{c}25 \\
0\end{array}$ & 0 & $\begin{array}{l}0 \\
0\end{array}$ & 1 & $\begin{array}{c}25 \\
, 0\end{array}$ & 4 \\
\hline $\begin{array}{l}\text { Wyższe I } \\
\text { stopnia }\end{array}$ & 3 & $\begin{array}{l}5, \\
0\end{array}$ & 23 & $\begin{array}{c}38 \\
3\end{array}$ & 17 & $\begin{array}{c}28 \\
3\end{array}$ & 2 & $\begin{array}{l}3, \\
3\end{array}$ & 15 & $\begin{array}{l}25 \\
, 0\end{array}$ & $\begin{array}{l}6 \\
0\end{array}$ \\
\hline $\begin{array}{ll}\text { Wyższe } & \text { II } \\
\text { stopnia } & \end{array}$ & 1 & $\begin{array}{l}14 \\
, 2\end{array}$ & 3 & 5,0 & 2 & $\begin{array}{c}28 \\
5\end{array}$ & 0 & $\begin{array}{l}0 \\
0\end{array}$ & 1 & $\begin{array}{l}14 \\
2\end{array}$ & 7 \\
\hline Test $-x^{2}$ & \multicolumn{10}{|c|}{1,5106} & \multirow{3}{*}{$\begin{array}{l}7 \\
1\end{array}$} \\
\hline Istotność - p & \multicolumn{10}{|c|}{0,993} & \\
\hline Razem - n & \multicolumn{10}{|c|}{71} & \\
\hline
\end{tabular}

Źródło: wynik badań własnych 


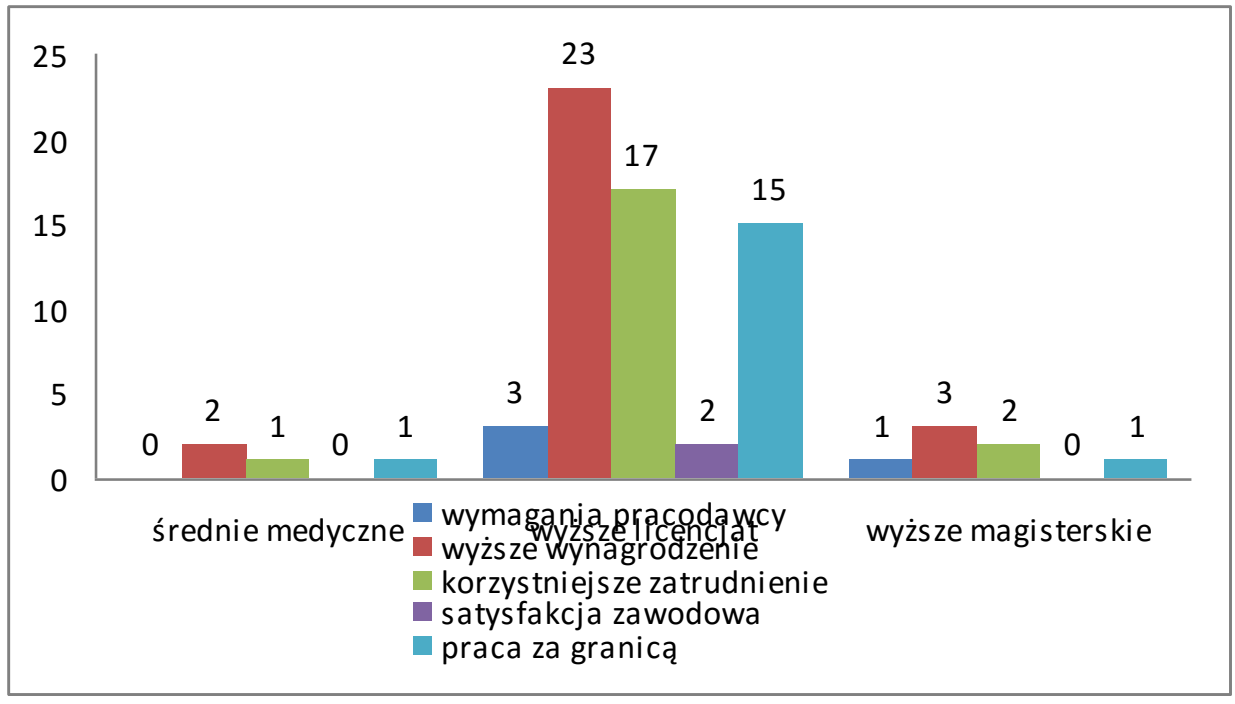

Rycina 2. Rozkład czynników wpływających na podnoszenie poziomu wykształcenia podyplomowego pielęgniarek, a poziom wykształcenia zawodowego osób badanych.

Źródło: wynik badań własnych

Analiza statystyczna nie wykazała istotnych zależności pomiędzy czynnikami wpływającymi na podnoszenie poziomu wykształcenia podyplomowego pielęgniarek a poziomem ogólnego wykształcenia zawodowego $(\mathrm{p}<0,993)$. Na każdym poziomie wykształcenia osób ankietowanych czynnikami decydującymi o podjęciu kształcenia podyplomowego jest wyższe wynagrodzenie i korzystniejsze warunki zatrudnienia. Czynniki te są najwyższe w grupie respondentów $\mathrm{z}$ wykształceniem wyższym na poziomie licencjatu.

W tabeli 3 i na rycinie 3 zaprezentowane zostały wyniki badań dotyczące wpływu zajmowanego stanowiska przez pielęgniarki na motywy podejmowania dokształcania i doskonalenia zawodowego. 
Tabela 3. Czynniki wpływające na podnoszenie poziomu wykształcenia podyplomowego pielęgniarek, a zajmowane stanowisko w pracy osób badanych.

\begin{tabular}{|c|c|c|c|c|c|c|c|c|c|c|c|}
\hline \multirow{2}{*}{$\begin{array}{l}\text { Czynniki } \\
\text { / } \\
\text { zajmowane } \\
\text { stanowisko }\end{array}$} & \multicolumn{2}{|c|}{$\begin{array}{c}\text { Wymaga } \\
\text { nia } \\
\text { pracoda } \\
\text { wcy } \\
\end{array}$} & \multicolumn{2}{|c|}{$\begin{array}{l}\text { Wyższa } \\
\text { pensja }\end{array}$} & \multicolumn{2}{|c|}{$\begin{array}{c}\text { Korzystn } \\
\text { e } \\
\text { zatrudnie } \\
\text { nie }\end{array}$} & \multicolumn{2}{|c|}{$\begin{array}{c}\text { Satysfakc } \\
\text { ja } \\
\text { zawodow } \\
\text { a }\end{array}$} & \multicolumn{2}{|c|}{$\begin{array}{c}\text { Praca za } \\
\text { granicą }\end{array}$} & \multirow{2}{*}{ 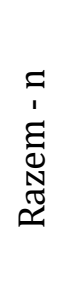 } \\
\hline & $\begin{array}{c}\mathrm{n} \\
=4\end{array}$ & $\%$ & $\begin{array}{l}n= \\
28\end{array}$ & $\%$ & $\begin{array}{l}n= \\
20\end{array}$ & $\%$ & $\begin{array}{c}\mathrm{n}= \\
2\end{array}$ & $\%$ & $\begin{array}{l}\mathrm{n}= \\
17\end{array}$ & $\%$ & \\
\hline $\begin{array}{l}\text { Pielęgniark } \\
\text { a } \\
\text { odcinkowa }\end{array}$ & 2 & 6,2 & 11 & $\begin{array}{c}34, \\
3\end{array}$ & 9 & $\begin{array}{c}28, \\
1\end{array}$ & 1 & 3,1 & 9 & $\begin{array}{c}28, \\
1\end{array}$ & 32 \\
\hline $\begin{array}{l}\text { Pielęgniark } \\
\text { a } \\
\text { zabiegowa }\end{array}$ & 1 & 4,0 & 10 & $\begin{array}{c}40, \\
0\end{array}$ & 7 & $\begin{array}{c}28, \\
0\end{array}$ & 1 & 4,0 & 6 & $\begin{array}{c}24, \\
0\end{array}$ & 25 \\
\hline $\begin{array}{l}\text { Pielęgniark } \\
\text { a } \\
\text { oddziałowa }\end{array}$ & 0 & 0,0 & 3 & $\begin{array}{c}75, \\
0\end{array}$ & 1 & $\begin{array}{c}25, \\
0\end{array}$ & 0 & 0,0 & 0 & $\begin{array}{c}0,0 \\
0\end{array}$ & 4 \\
\hline Inne & 1 & $\begin{array}{c}10, \\
0\end{array}$ & 4 & $\begin{array}{c}40, \\
0\end{array}$ & 3 & $\begin{array}{c}30, \\
0\end{array}$ & 0 & 0,0 & 2 & $\begin{array}{c}20, \\
0\end{array}$ & 10 \\
\hline Test $-X^{2}$ & \multicolumn{10}{|c|}{2,53} & \multirow{3}{*}{71} \\
\hline Istotność - p & \multicolumn{10}{|c|}{0,998} & \\
\hline Razem - n & \multicolumn{10}{|c|}{71} & \\
\hline
\end{tabular}

Źródło: wynik badań własnych 


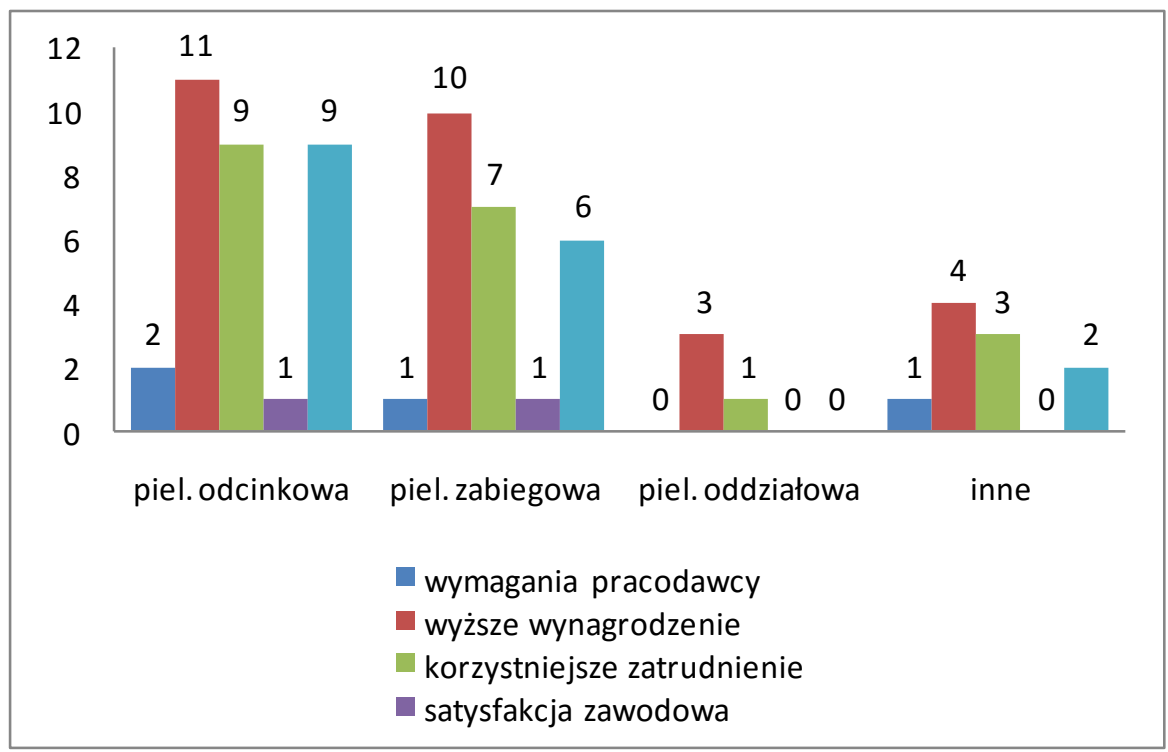

\section{Rycina 3. Rozkład czynników wpływających na podnoszenie poziomu wykształcenia podyplomowego pielęgniarek, a zajmowane stanowisko w pracy osób badanych. \\ Źródło: wynik badań własnych}

Analiza statystyczna nie wykazała istotnych zależności pomiędzy czynnikami wpływającymi na podnoszenie poziomu wykształcenia podyplomowego pielęgniarek, a zajmowanym stanowiskiem $\mathrm{w}$ pracy $(\mathrm{p}<0,998)$. Na każdym zajmowanym stanowisku przez pielęgniarki czynnikami powodującymi podejmowanie kształcenia podyplomowego są wyższe wynagrodzenie, korzystniejsze warunki zatrudnienia oraz ewentualne podjęcie pracy zawodowej za granicą. Zauważyć jednak można, że czynniki te są najwyższe w grupie zawodowej pielęgniarek odcinkowych. 
Tabela 4. Czynniki wpływające na podnoszenie poziomu wykształcenia podyplomowego pielęgniarek, a staż pracy osób badanych.

\begin{tabular}{|c|c|c|c|c|c|c|c|c|c|c|c|}
\hline \multirow{2}{*}{$\begin{array}{l}\text { Czynniki } \\
\text { / staż } \\
\text { pracy }\end{array}$} & \multicolumn{2}{|c|}{$\begin{array}{c}\text { Wymaga } \\
\text { nia } \\
\text { pracodaw } \\
\text { cy }\end{array}$} & \multicolumn{2}{|c|}{$\begin{array}{c}\text { Wyższe } \\
\text { wynagrod } \\
\text { zenie }\end{array}$} & \multicolumn{2}{|c|}{$\begin{array}{l}\text { Korzystni } \\
\text { ejsze } \\
\text { zatrudnie } \\
\text { nie }\end{array}$} & \multicolumn{2}{|c|}{$\begin{array}{c}\text { Satysfakcj } \\
\text { a } \\
\text { zawodow } \\
\text { a }\end{array}$} & \multicolumn{2}{|c|}{$\begin{array}{c}\text { Praca za } \\
\text { granicą }\end{array}$} & \multirow{2}{*}{ 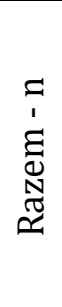 } \\
\hline & $\begin{array}{c}\mathrm{n}= \\
4\end{array}$ & $\%$ & $\begin{array}{l}\mathrm{n}= \\
28\end{array}$ & $\%$ & $\begin{array}{l}\mathrm{n}= \\
20\end{array}$ & $\%$ & $\begin{array}{c}\mathrm{n}= \\
2\end{array}$ & $\%$ & $\begin{array}{l}\mathrm{n}= \\
17\end{array}$ & $\%$ & \\
\hline $1-10$ lat & 2 & $\begin{array}{c}6,2 \\
5\end{array}$ & 11 & $\begin{array}{l}34, \\
37\end{array}$ & 9 & $\begin{array}{l}28, \\
12\end{array}$ & 0 & $\begin{array}{c}3,1 \\
2\end{array}$ & 7 & $\begin{array}{l}28, \\
12\end{array}$ & 29 \\
\hline $11-20$ lat & 1 & $\begin{array}{c}4,0 \\
0\end{array}$ & 9 & $\begin{array}{l}40 \\
00\end{array}$ & 7 & $\begin{array}{l}28, \\
00\end{array}$ & 2 & $\begin{array}{c}4,0 \\
0\end{array}$ & 6 & $\begin{array}{l}24, \\
00\end{array}$ & 25 \\
\hline $21-30$ lat & 1 & $\begin{array}{c}0,0 \\
0\end{array}$ & 8 & $\begin{array}{l}75, \\
00\end{array}$ & 4 & $\begin{array}{l}25, \\
00\end{array}$ & 0 & $\begin{array}{c}0,0 \\
0\end{array}$ & 4 & $\begin{array}{c}0,0 \\
0\end{array}$ & 17 \\
\hline Test $-X^{2}$ & \multicolumn{10}{|c|}{4,48} & \multirow{3}{*}{71} \\
\hline $\begin{array}{l}\text { Istotność } \\
-\mathrm{p}\end{array}$ & \multicolumn{10}{|c|}{0,973} & \\
\hline $\begin{array}{l}\text { Razem } \\
\mathrm{n}\end{array}$ & \multicolumn{10}{|c|}{71} & \\
\hline
\end{tabular}

Źródło: wynik badań własnych 


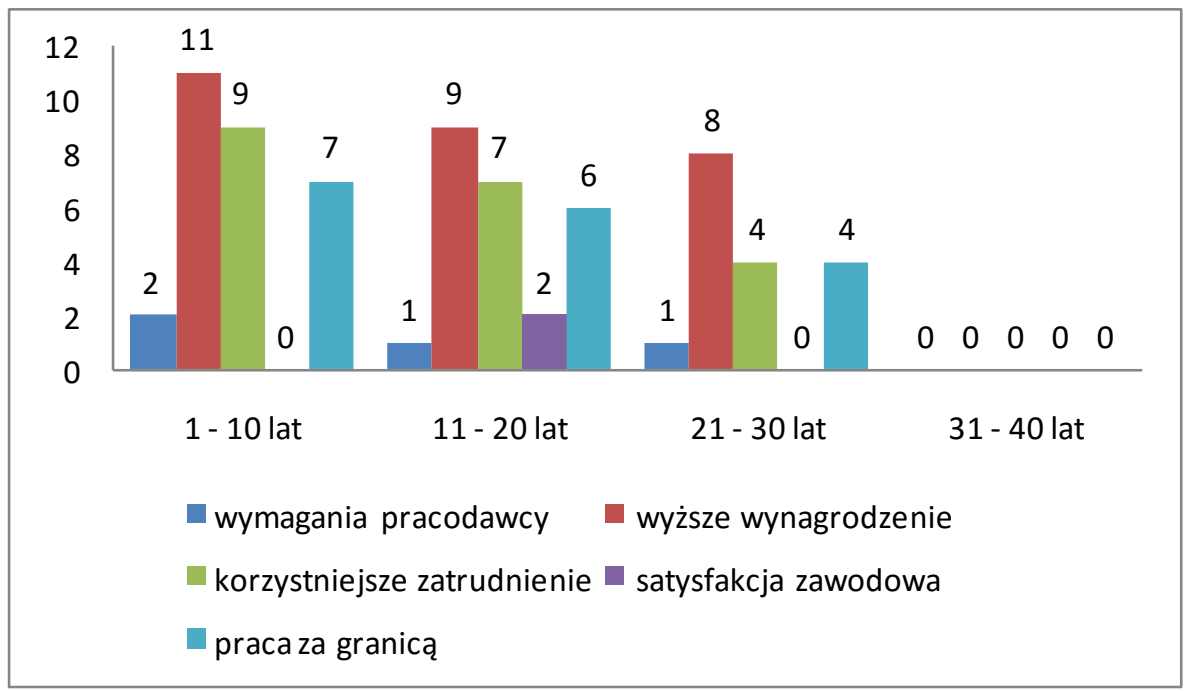

Rycina 4. Rozkład czynników wpływających na podnoszenie poziomu wykształcenia podyplomowego pielęgniarek, a staż pracy osób badanych.

Źródło: wynik badań własnych

Analiza statystyczna nie wykazała istotnych zależności pomiędzy czynnikami wpływającymi na podnoszenie poziomu wykształcenia podyplomowego pielęgniarek a stażem pracy zawodowej $(\mathrm{p}<0,973)$. Na każdym etapie pracy zawodowej czynnikami, które przeważają są wyższe wynagrodzenie, korzystniejsze warunki zatrudnienia oraz ewentualne podjęcie pracy zawodowej za granicą. Jednakże należy zauważyć, że czynniki te dominują wśród pielęgniarek z krótszym stażem pracy w porównaniu z pielęgniarkami mającymi długi staż pracy.

\section{Dyskusja}


Dokonująca się metamorfoza gospodarki krajowej w latach osiemdziesiątych XX wieku sięgnęła również sektorów publicznych. Służba zdrowia w tym okresie przechodziła wiele zmian i reform. W początkowej fazie tego okresu reformy dotyczyły zasad finansowania świadczeń, planowania kosztów, refundacji poniesionych wydatków. W następnych dekadach zmiany zaczęły dotyczyć jakości usług. Wiązało się to $\mathrm{z}$ wprowadzaniem nowoczesnego sprzętu diagnostyczno-zabiegowego. Zaczęto opracowywać algorytmy i standardy działań. Personel pomocniczy, pielęgniarski jak również lekarski rozpoczął intensywny proces dokształcania i podnoszenia własnych kompetencji i umiejętności.

Analiza wyników badań własnych wykazała, że głównym czynnikiem motywującym osoby ankietowane do podjęcia procesu dokształcania jest czynnik finansowy i związane $\mathrm{z}$ tym wyższe wynagrodzenie. Takiej odpowiedzi udzieliło aż 39,4 \% osób badanych. Drugim czynnikiem motywującym osoby badane do rozpoczęcia procesu dokształcania jest uzyskanie korzystniejszych warunków zatrudnienia co stanowi $28,2 \%$ udzielonych odpowiedzi wśród osób ankietowanych. Natomiast aż 22,5 \% osób objętych badaniem ankietowym uznało, że $\mathrm{w}$ ich przypadku głównym czynnikiem motywującym do kształcenia podyplomowego jest podjęcie pracy w zawodzie za granicą. Wszystkie te trzy odpowiedzi bezpośrednio lub pośrednio dotyczą sfery finansowej. Łącznie te odpowiedzi stanowią ponad $90 \%$ wszystkich udzielanych odpowiedzi.

Badania własne ukazały również poziom satysfakcji płynący z procesu dokształcania przez pielęgniarki i pielęgniarzy. Aż 80,1\% osób objętych badaniem ankietowym odczuwa satysfakcję z tego, ze podjęła proces kształcenia podyplomowego. Natomiast $60 \%$ osób ankietowanych udzieliło odpowiedzi, że są doceniani przez przełożonych i współpracowników w związku z podnoszeniem kwalifikacji zawodowych.

Proces dokształcania wśród pielęgniarek i pielęgniarzy rozpoczął się po wejściu Polski do Unii Europejskiej. Zmiany 
legislacyjne polskiego prawa, możliwość wyjazdu do pracy w krajach członkowskich wspólnoty europejskiej otworzyły nowe możliwości dla pielęgniarek i pielęgniarzy. Możliwość pozyskania funduszy unijnych w ramach Kapitału Ludzkiego na dokształcanie w latach 2007-2013 w znaczący sposób umożliwiły bezpłatnie ukończenie szeregu szkół i kursów dokształcających. W tym okresie przypada największy odsetek osób czynnych zawodowo podejmujących dokształcanie i doskonalenie podyplomowe.

Dokonując analizy piśmiennictwa zwrócono uwagę na dość liczne publikacje zawierające sprawozdania z wykonanych badań na temat kształcenia podyplomowego pielęgniarek. W 2007 roku zostały przeprowadzone badania mające na celu określenie motywów podwyższania wykształcenia przez pielęgniarki Wojewódzkiego Szpitala Zespolonego w Elblągu. Autorami tych badań są E. Bidzińska, M. Sobczak, K. Rakowska. Grupę badaną stanowiło 69 pielęgniarek i pielęgniarzy o zróżnicowanych cechach demograficznych i zawodowych. Badania te wykazały, że głównym motywem podejmowania kształcenia podyplomowego przez pielęgniarki elbląskiego szpitala jest chęć pogłębiania wiedzy i umiejętności - 60,9 $\%$ wszystkich odpowiedzi. Drugim motywem wpływającym na podjęcie procesu dokształcania była możliwość uzyskania przez szpital certyfikatu akredytacyjnego - 34,8 \% odpowiedzi. Na trzecim miejscu znalazła się odpowiedź „możliwość podwyższenia wynagrodzenia”, co stanowi $21,7 \%$ [3].

Natomiast w 2010 roku zostały opublikowane badania przeprowadzone przez E. Krupińską pt. Kształcenie podyplomowe pielęgniarek - potrzeba czy obowiązek. Badania przeprowadzono wśród 113 pielęgniarzy i pielęgniarek. Osoby ankietowane pochodziły $\mathrm{z}$ różnych rejonów Polski. 33 osoby pochodziły $\mathrm{z}$ województwa śląskiego, 13 osób z mazowieckiego, 10 osób z małopolskiego, 9 osób z pomorskiego, 8 osób $\mathrm{z}$ lubuskiego, po 6 osób z zachodniopomorskiego i świętokrzyskiego, po 5 osób z dolnośląskiego i łódzkiego, po 4 osoby z lubelskiego, podkarpackiego 
i kujawsko-pomorskiego. Wśród wymienianych motywów podnoszenia kwalifikacji najczęściej było to odczuwanie potrzeby zwiększenia kompetencji zawodowych i poziomu świadczonej opieki wobec pacjentów. Na trzecim miejscu znalazła się odpowiedź dotycząca zmiany pracy na lepiej płatną [4].

W 2015 roku zostały przeprowadzone i opublikowane badania na Warszawskim Uniwersytecie Medycznym ukazujące systemy motywacyjne w pracy pielęgniarek. Badania zostały wykonane przez zespół badawczy U. Błazuk i H. Cieślak. Badania przeprowadzono wśród 100 studentek kierunku pielęgniarstwa czynnych zawodowo. Z przeprowadzonych badań wynika, że bodźcami najbardziej motywującymi do podjęcia kształcenia podyplomowego jest wyższe wynagrodzenie oraz podnoszenie kwalifikacji i kompetencji zawodowych [5].

Na podstawie powyższych publikacji i badań własnych można zauważyć proces przesuwania się motywatorów finansowych przy podjęciu decyzji o dokształcaniu z niższych stopni odpowiedzi na coraz to wyższe miejsca w hierarchii odpowiedzi. Badania własne i analiza piśmiennictwa rozpiętością swą obejmują okres 10 lat od 2007 do 2017 roku. To w tym okresie największy odsetek osób czynnych zawodowo podnosił swoje kwalifikacje zawodowe. Odnosząc ten proces do danych Głównego Urzędu Statystycznego dotyczących przeciętnego wynagrodzenia brutto pielęgniarek $w$ Polsce, a przeciętnego wynagrodzenia brutto $\mathrm{w}$ sektorze przedsiębiorstw, można zauważyć, że im większa dysproporcja w zarobkach pielęgniarek, a sektorem przedsiębiorstw tym wyższe miejsce motywatora finansowego $\mathrm{w}$ badaniach ankietowych. Według danych Głównego Urzędu Statystycznego na koniec roku 2014 średnie wynagrodzenie brutto wśród pielęgniarek wynosiło 3400 złotych, natomiast średnie wynagrodzenie brutto $\mathrm{w}$ sektorze przedsiębiorstw wyniosło 4379 złotych. W publikacjach od 2015 roku jak i własnych badaniach najczęściej wymienianym motywatorem podjęcia 
kształcenia podyplomowego wśród pielęgniarek i pielęgniarzy jest chęć zwiększenia wysokości zarobków.

\section{Wnioski}

1. Główne czynniki wpływające na podejmowanie kształcenia podyplomowego pielęgniarek $\mathrm{w}$ opinii osób badanych to określone czynniki zawodowe i osobiste:

- chęć uzyskania wyższego wynagrodzenia,

- korzystniejsze warunki zatrudnienia,

- podjęcie pracy zawodowej za granicą,

- wymagania pracodawcy,

- satysfakcja zawodowa.

2. Czynniki wpływające na podjęcie decyzji o rozpoczęciu procesu dokształcania nie zależą od wykształcenia zawodowego osób badanych.

3. Czynniki wpływające na podjęcie decyzji o rozpoczęciu procesu dokształcania nie zależą od zajmowanego stanowiska w pracy zawodowej osób badanych.

4. Czynniki wpływające na podjęcie decyzji o rozpoczęciu procesu dokształcania nie zależą od stażu pracy osób badanych.

\section{Bibliografia/Bibliography:}

1. www.isejm.gov.pl 15.12.2016r.

2. Jarzynowski P., Piotrowska R., Książek J., System kształcenia pielęgniarek $\mathrm{w}$ wybranych krajach Europy i Stanach Zjednoczonych. GUM. 2010;230-245.

3. Bidzińska E., Sobczak M., Rakowska K., Motywy podwyższania wykształcenia przez pielęgniarki Wojewódzkiego Szpitala 
Zespolonego w Elblągu. Problemy Pielęgniarstwa. 2007;2-3:198202.

4. Krupińska E., Kształcenie podyplomowe pielęgniarek. Wrocławski Uniwersytet Medyczny. 2010.

5. Błazucka U., Cieślak H., Systemy motywacyjne w pracy pielęgniarki. Pielęgniarstwo Polskie. 2015;3(57):283-287. 